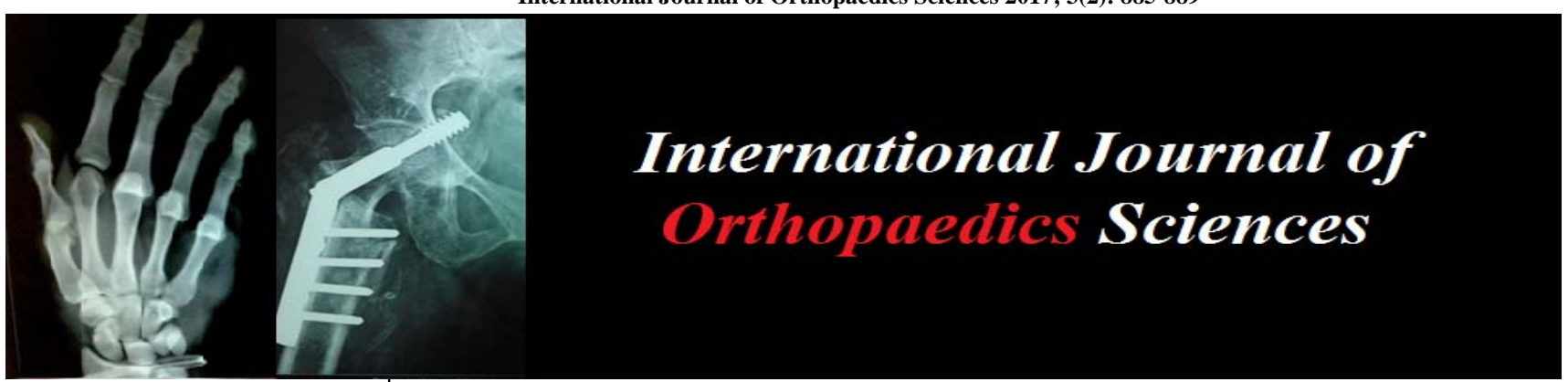

ISSN: $2395-1958$

IJOS 2017; 3(2): 885-889

(C) 2017 IJOS

www.orthopaper.com

Received: 07-02-2017

Accepted: 08-03-2017

Dr Vijay Khariwal

Chairman Institute of Orthopedics Spine Traumatology and Rehabilitation Jaipur Golden Hospital Rohini Sec 3 Delhi, India.

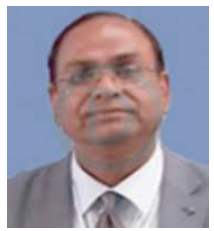

Dr. Sanjay Chhawra

Consultant Jaipur Golden Hospital Rohini Sec 3 Delhi, India.

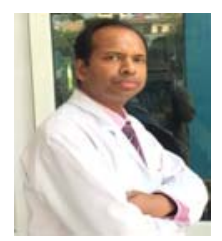

Dr. Ravi Gupta

Clinical Associate Jaipur Golden Hospital Rohini Sec 3 Delhi, India.
Correspondence

Dr. Vijay Khariwal

Chairman Institute of

Orthopedics Spine Traumatology

and Rehabilitation Jaipur

Golden Hospital Rohini Sec 3

Delhi, India.

\section{A rare case report at rare site tuberculosis of sacrum sacroiliac joint with gluteal abscess indication for drainage of cold abscess which usually treated by conservative treatment}

\author{
Dr. Vijay Khariwal, Dr. Sanjay Chhawra and Dr. Ravi Gupta
}

DOI: http://dx.doi.org/10.22271/ortho.2017.v3.i2j.97

\section{Abstract}

Introduction: Tuberculosis remains a major public problem for the developing countries. Osteoarticular tuberculosis represents $2 \%$ to $5 \%$ of all cases of tuberculosis, in that the sacroiliac joint is involved in 3$9.7 \%$. Isolated tuberculosis of the sacrum is rarely reported; with Sacroiliac joint infections represent a diagnostic dilemma for their vague and non-specific clinical presentation.

Case report: A 26 yr Female presented with Pain, Swelling over left Buttock since 2 month with Low Backache, Limping was present with Constitutional symptom Loss of Appetite, Low grade Fever, Weight Loss. Patient was investigated then planned for surgery incision and drainage curettage was done and sends for biopsy. After laboratory tests diagnosed Tuberculosis Osteomyelitis and after proper duration of ATT drugs patient was cured.

Conclusion: So it is rare case at rare site Sacrum with reactionary Sacroiliac joint Tuberculosis with Gluteal Abscess. Clinical diagnosis of sacroiliac joint infection includes a thorough history and a meticulous examination of the lower back and the sacroiliac joint. Tuberculous sacroiliitis should be differentiated with various disorders. After confirmation of diagnosis with support of clinical features blood report biopsy ATT drugs given with proper duration and doses in Follow up serial $\mathrm{x}$ rays and bloods test was done. The prognosis of sacral tuberculosis is good, if a rapid and correct diagnosis is made and adequate treatment is provided with proper duration and drugs doses Indication of drainage of cold abscess was because It large volume which cannot treated conservatively, pressure effect causing severe pain, difficulty in sitting, definitive diagnosis of Infective Pathology.

Keywords: Tuberculosis SI joint Osteomyelitis

\section{Introduction}

Tuberculosis can affect any bone and joint structures of the body. Osteoarticular tuberculosis represents $2 \%$ to $5 \%$ of all cases of tuberculosis and $11 \%$ to $15 \%$ of extra pulmonary tuberculosis ${ }^{[15]}$. The sacroiliac joint is involved in 3-9.7\%. Isolated tuberculosis of the sacrum is rarely reported, which leads to a delay in diagnosis and subsequently persistence of a normally curable disease. Tuberculosis remains a major public problem for the developing countries. Sacroiliac joint infections represent a diagnostic dilemma for their vague and nonspecific clinical presentation ${ }^{[19]}$

\section{Case Report}

A 26 yr Female presented with Pain Swelling over left Buttock since 2 month with Low Backache Limping present Constitutional symptom Loss of Appetite, Low grade Fever, Weight Loss Pallor was present in Past history had no other medical illness.

Local examination Tenderness and swelling over left side of buttock SI Joint Posterior aspect of Hip Joint Gaenslen test was Positive FABER Test was Positive Forced Flexion Abduction External Rotation of Hip joint is very painful Straight Leg Raising SLR Negative Neurology was normal. Patient was investigated Routine Blood test ESR CRP was raised X ray Chest Xray was normal. 


\section{Lab Report}

\begin{tabular}{|c|c|}
\hline Microbiology & Result \\
\hline AFB & Negative \\
\hline PUS Culture & Sterile \\
\hline Gram Stain & No Organism \\
\hline PCR FOR TB & Mycobacterium TB Complex detected \\
\hline GENE XPERT MTB & Detected Low \\
\hline
\end{tabular}

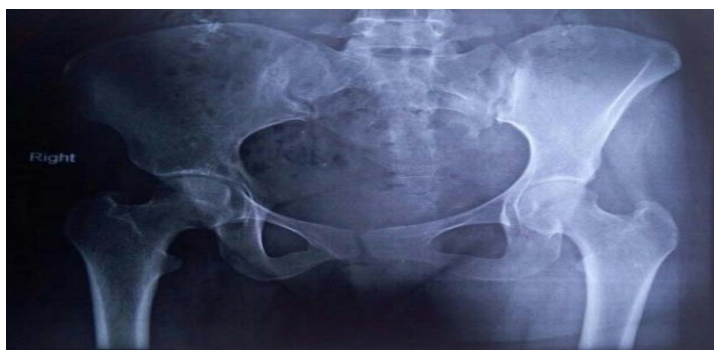

Fig 1: X RAY Sclerosis Wide - Left SI Joint Sequestra

MRI - Irregular Erosion with Marrow edema of left side of sacrum invoving S2 S3 with left Gluteal 10-10-5 cm collection Left G. Maximus Pyriformis involved Both HIP Jt other Pelvic bone both S.I Jts normal Impression Osteomyelitis of left Sacrum with Irregular septated presacral Gluteal with left Gluteal 10-10-5 cm collection

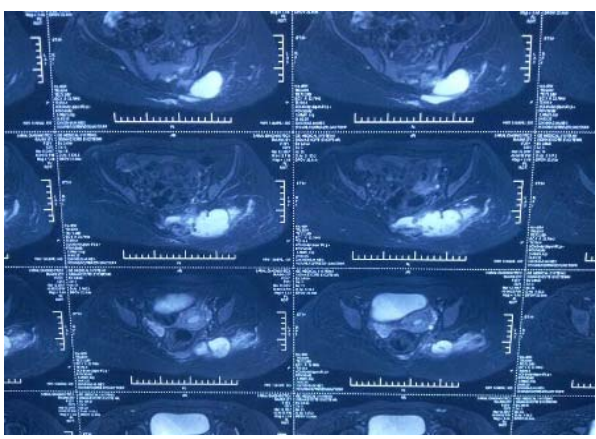

Fig 2: MRI

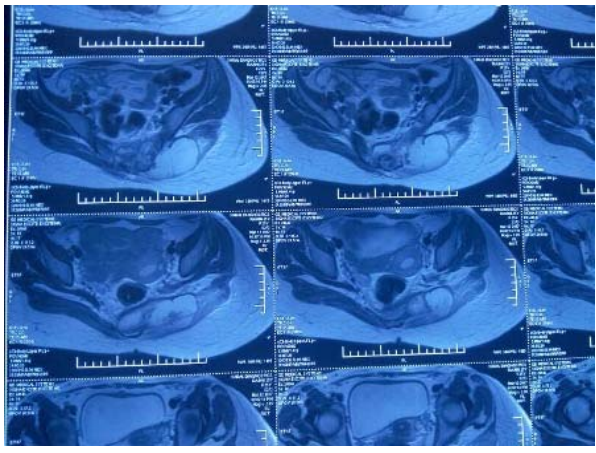

Fig 3: MRI

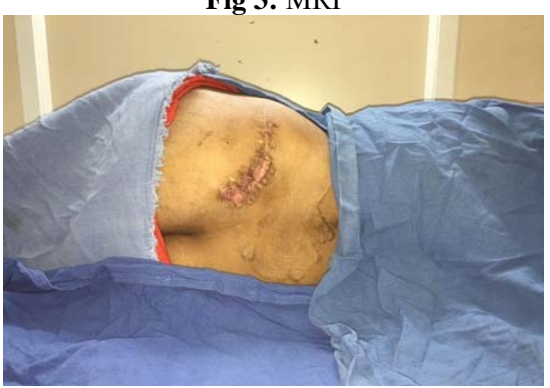

Fig 4: Incision drainage Scar

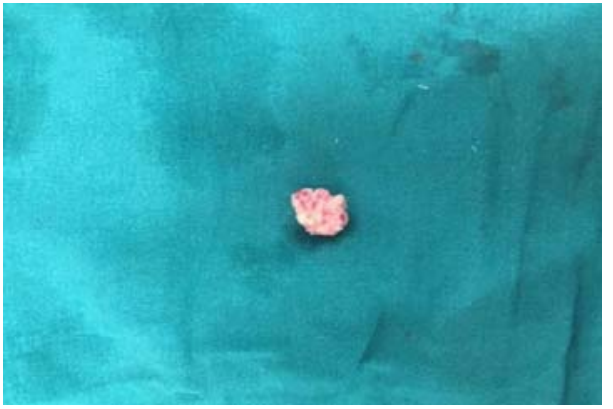

Fig 5: Bone Sequestra

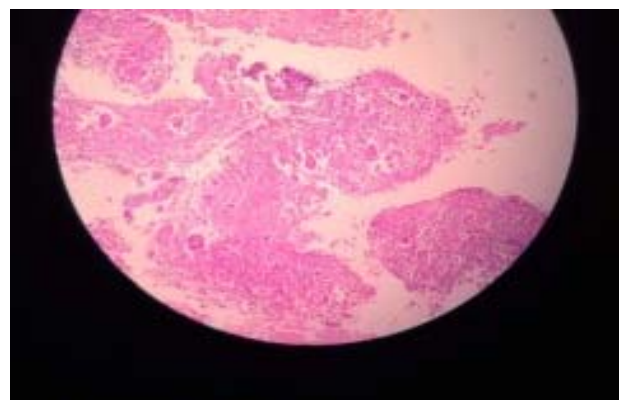

Fig 6: Laboratory Slide

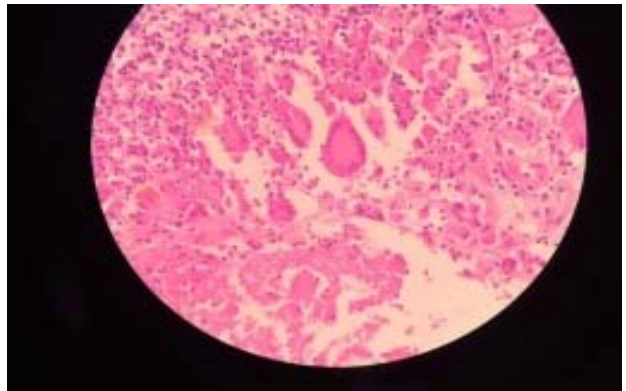

Fig 7: Laboratory Slide

Patient was then planned for surgery incision and drainage curettage was done from posterior aspect the inflamed tissue was send was for Biopsy the bone sequestra was drained out which was also send for biopsy.

Histopathology - Soft Tissue: Multiple grey friable soft tissue Well form epitheloid granulomas with langhran gaint cell chronic inflammatory cell caseation necrosis dead bony fragment $[18,19]$

Bone: $2.5 \mathrm{~cm}$ Large amount of Caseation necrosis few chronic inflammatory cell dead bony fragment Impression Tuberculosis Osteomyelitis

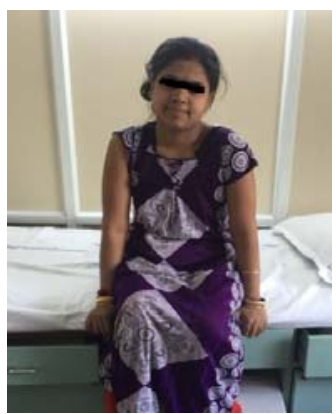

Fig 8: Post-operative Outcome was good 

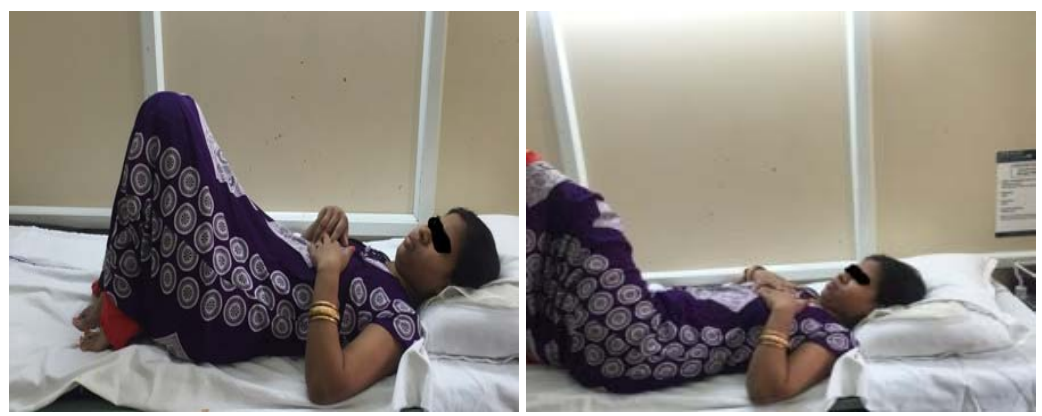

Fig 9, 10: Post-operative Outcome was good

The Patient was started with ATT Anti Tubercular Drugs ${ }^{[47]}$ and supportive. Patient Pain Swelling Limping was tremendously decreased, Outcome was satisfactory with constitutional symptom improved. At final follow-up, the patients had minimal discomfort over the affected joint and were fully weight bearing.

\section{Discussion}

Tuberculosis is a major health problem in developing countries. In 1779 by Percival Pott described the osteo articular tuberculosis represents about $3 \%$ of all tuberculosis and $15 \%$ of extra pulmonary tuberculosis. Bone and joint tuberculosis accounts for about $10.2 \%$ of patients with extra pulmonary tuberculosis of which $8.8 \%$ is spinal disease.' $[35,36$, 38]

Spinal location at the thoracolumbar spine in $80 \%$ of cases. Isolated tuberculosis of the sacrum is rarely reported in the literature ${ }^{[1,2]}$ with a frequency estimated at $5 \%$ by Pertuiset $e t$ al [37]. In a review of 63 cases of spinal tuberculosis by Lindahl et al ${ }^{[29]}$, sacral involvement was found in just four cases, while none was involved in 107 patients in the series of Lifeso et al. ${ }^{[30}$ 39]

Spinal tuberculosis is often due to hematogenous spread of mycobacteria from primary foci in the lung and/or genitourinary tract. It is widely believed that the paravertebral venous plexus of Batson provides the primary pathway for dissemination of the tuberculous bacilli into the vertebral column. It is also possible that lymphatic drainage of the pleura or kidney may involve the para-aortic lymph nodes, which may secondarily involve the vertebrae. ${ }^{[9,39,41-43]}$

Clinical manifestations of sacral tuberculosis depend primarily on the age of the patient. Presenting symptoms and signs of sacroiliac tuberculosis ${ }^{[3-5]}$ are often insidious and localized to that joint. Pain is the most common initial symptom ${ }^{[6-9]}$. Because of its location deep in the pelvis, most of the classical signs of a peripheral joint inflammationswelling, redness and warmth-are not present so that infection may easily be over looked ${ }^{[11-14,25]}$. Buttock pain is invariably present in tuberculous sacroiliitis. The sacroiliac pain can be referred to the groin, posterior thigh, and occasionally below the knee, mimicking pain originating from the lumbar spine, the hip and the lower abdominal quadrant. There may be signs of femoral or sciatic nerve root irritation if the distended anterior joint capsule comes in contact with the lumbosacral plexus. In a series, Richter et al. ${ }^{[43]}$ reported that $92 \%$ of patients were misdiagnosed and were initially treated for lumbosacral radiculopathy,

Tenderness over the SI joint and one or more positive SI joint stress tests are present in most patients ${ }^{[38,39]}$. X-rays of the SI joint may be normal in the early stage of the disease ${ }^{[10]}$. Subsequently, haziness and/or loss of the joint line, irregularity of the articular surface and subchondral erosions appear. In later stages, destructive lesions become more distinct and cavitations develop. Fusion of the SI joint can occur within 3-4 years of onset of medical treatment $[16,17,48$, $49,50]$

Tuberculous sacroiliitis should be differentiated from degenerative and post-traumatic arthritis; pyogenic infection of the sacroiliac joint; connective tissue disorders such as rheumatoid arthritis and systemic lupus erythematosus; tumors and tumor like conditions, and pigmented villonodular synovitis ; inflammatory diseases such as sero-negative spondyloarthropathies, ankylosing spondylitis, psoriatic arthritis, Reiter's and Behçet's syndromes and inflammatory bowel diseases; familial Mediterranean fever with multisystem involvement including arthritis; osteitis condensans ilii; metabolic conditions such as gout pseudogout and hyperparathyroidism ${ }^{[26]}$.

MRI of the sacrum usually reveals diffuse marrow edema that is hypointense on T1- and hyperintense on T2-weighted images. The tubercular lesions may be misinterpreted with other infectious diseases or neoplasms in MRI. ${ }^{23,24,28,29,30]}$

CT is useful for imaging cortical bone. However, the early marrow changes in the vertebrae that precede the more gross erosive changes are difficult to visualize. [44, 46] Plain radiographs are extremely insensitive and do not detect vertebral involvement until at least $50 \%$ of a vertebra is destroyed.

Surgical biopsy is needed in diagnosis of certainty tuberculosis by a pathological study. This surgical biopsy was performed in our patient ${ }^{[33]}$.

The diagnosis is made by isolation of mycobacteria either by AFB stain or by culture. CT-scan-guided needle aspiration can also done in early suspected cases. Pouchot et al. have reported that closed-needle biopsy technique was more accurate and reliable. The tuberculin skin test is usually positive in skeletal TB." A positive PPD is, however, not specific for current infection, and on occasion may be negative in active disease.

After confirmation of diagnosis ATT drugs given for 12 Months with serial $x$ rays bloods test. The prognosis of sacral tuberculosis is good, if a rapid and correct diagnosis is made and adequate treatment is provided.

\section{Conclusion}

So it is rare case at rare site Sacrum with reactionary Sacroiliac joint Tuberculosis with Gluteal Abscess Indeed in MRI it was mentioned normal Sacroiliac joint. A clinical diagnosis of sacroiliac joint infection includes a thorough history and a meticulous examination of the lower back and the sacroiliac joint. Isolated sacral tuberculosis is exceptional and often causes a delay in diagnosis. It should always be 
suspected in any process of the lytic sacrum, especially in endemic areas of tuberculosis, to prevent or at least reduce the morbidity of this disease, which is generally curable. Indication of drainage of cold abscess was because It large volume, pressure effect causing severe pain, Large volume cannot be treated conservatively, difficulty in sitting, definitive diagnosis of Infective Pathology of Sacrum SI Joint which can be treated conservatively (FNAC or on clinical diagnosis starting ATT treatment) Evidence of calcification, sequestrate and joint destruction on X-ray or CT scan is suggestive of tuberculosis infection. In the early stages of the infection aspiration using a closed needle biopsy is recommended ${ }^{[21]}$. An open biopsy is essential when the aspirate yields no growth and in patients who present late with severe joint destruction and collection as in our patient. After confirmation of diagnosis with support of clinical features blood report biopsy ATT drugs given with proper duration (12 months) and doses in Follow up serial $\mathrm{x}$ rays and bloods test was done. The prognosis of sacral tuberculosis is good, if a rapid and correct diagnosis is made and adequate treatment is provided with proper duration and drugs doses.

\section{References}

1. Attarian DE. Septic sacroiliitis: the overlooked diagnosis. J South Orthop Assoc 2001; 10(1):57-60[PubMed]

2. Babhulkar SS. Clinical comment. Clin Orthop 2002; 398:2-3

3. Bouajina E, Harzallah L, Hachfi W, Slama KB, Rammeh $\mathrm{N}$, Ghannouchi $\mathrm{M}$ et al. Tuberculous sacro-iliitis: a series of twenty-two cases. Rev Med Interne 2005; 26:690-4.

4. Benchakroun M, El Bardouni A, Zaddoug O, Kharmaz $\mathrm{M}$, Lamrani MO, El Yaacoubi $\mathrm{M}$ et al. Tuberculous sacroiliitis. Four cases. Joint Bone Spine. 2004; 71(2):150-153. doi: 10.1016/S1297-319X(03)00153-

5. Bernard TN, Jr, Cassidy JD. The sacroiliac joint syndrome. Pathophysiology, diagnosis, and management. In: Frymoyer JW, editor. The adult spine: principles and practice. Philadelphia: Lippincott-Raven. 1997, 23432366.

6. Bernard TN, Jr, Kirkland-Willis WH. Recognizing specific characteristics of nonspecific low back pain. Clin Orthop. 1987; 217:266-280. [PubMed]

7. Bonica JJ. The sacroiliac joint syndrome. Pathophysiology, diagnosis, and management. In: Frymoyer JW, editor. Anatomic and physiologic basis of nociception and pain. Philadelphia: Lea \& Febinger; 1990, 18-27.

8. Brasseur P, Koral E, Sukkarieh F, Vanhaeverbeek M, Bissen L. Tuberculous sacroiliitis: report of a case. Rev Med Brux. 2004; 25(2):99-102. [PubMed]

9. Bezer M, Kucukdurmaz F, Aydin N, Kocaoglu B, Guven O. Tuberculous spondylitis of the lumbosacral region: long-term follow-up of patients treated by chemotherapy, transpedicular drainage, posterior instrumentation, and fusion. J Spinal Disord Tech. 2005; 18:425-9.

10. Burrill J, Williams C, Bain G, Conder G, Hine AL, Misra RR. Tuberculosis: a radiologic review. Radiographics 2007; 27:1255-73.

11. Chen WS. Chronic sciatica caused by tuberculous sacroiliitis-a case report. Spine 1995; 20(10):11941196[PubMed]

12. Coy JT, Wolf CR, Brower TD, Winter WG. Pyogenic arthritis of the sacro-iliac joint. Long-term follow-up.J Bone Joint Surg Am 1976; 58(6):845-849 [PubMed]

13. Center Morbidity and Mortality Weekly Report. 2002;
51:101. [PubMed]

14. Davidson PT, Horowitz I. Skeletal tuberculosis. A review with patient presentations and discussion. Am J Med. 1970; 48(1):77-84. [PubMed]

15. Davies PD, Humphries MJ, Byfield SP, Nunn AJ, Darbyshire JH, Citron KM, Fox W Bone and joint tuberculosis. A survey of notifications in England and Wales. J Bone Joint Surg Br 1984; 66(3):326330[PubMed]

16. Dunn EJ, Bryan DM, Nugent JT, Robinson RA. Pyogenic infections of the sacroiliac joint. Clin Orthop 1976; 118:113-118 [PubMed]

17. Feldmann JL, Menkes CJ, Weill B, Delrieu F, Delbarre F. Infectious sacroiliitis Multicenter study of 214 cases. Rev Rhum Mal Osteoartic. 1981; 48(1):83 91. [PubMed\}

18. Goldberg J, Kovarsky J. Tuberculous sacroiliitis. South Med J. 1983; 76(9):1175-1176 [PubMed]

19. Gordan G, Kabins SA. Pyogenic sacroiliitis. Am J Med 1980; 69:50-56 [PubMed]

20. Kumar A, Varshney MK, Trikha V. Unusual presentation of isolated sacral tuberculosis. Joint Bone Spine. 2006; 73:751-2.

21. Hendrix RW, Lin PJ, Kane WJ. Simplified aspiration or injection technique for the sacroiliac joint. J Bone Joint Surg Am 1982; 64(8):1249-1252 [PubMed]

22. Isaacson AS, Whitehouse WM. Spontaneous sacroiliac obliteration in patients with tuberculosis. J Bone Joint Surg Am 1949; 31(2):306-311 [PubMed]

23. Kim NH, Lee HM, Suh JS. Magnetic resonance imaging for the diagnosis of tuberculous spondylitis. Spine 1994; 19(21):2451-2455 [PubMed]

24. Kim NH, Lee HM, Yoo JD, Suh JS. Sacroiliac joint tuberculosis-classification and treatment. Clin Orthop 1999; 358:215-222 [PubMed]

25. Laslett $M$, Williams $M$. The reliability of selected pain provocation tests for sacroiliac joint pathology. Spine. 1994; 19(11):1243-1249. [PubMed]

26. Lumbered KM, Kissane JM. Clinic pathologic conference. Severe right hip pain in a 73-year-old woman. Am J Med. 1986; 81(1):117-124. Doi: 10.1016/0002-9343(86)90192-0. [PubMed

27. Lynch AF. Tuberculosis of the greater trochanter. A report of eight cases. J Bone Joint Surg [Br] 1982; 64(2):185-188. [PubMed]

28. Hong SH, Kim SM, Ahn JM, Chung HW, Shin MJ, Kang HS. Tuberculous versus pyogenic arthritis: MR imaging evaluation. Radiology. 2001; 218(3):848-853. [PubMed

29. Lindahl S, Nyman RS, Brismar J, Hugosson C, Lundstedt C. Imaging of tuberculosis. IV. Spinal manifestations in 63 patients. Acta Radiol 1996; 37:506-11.

30. Lifeso RM, Weaver P, Harder EH. Tuberculosis spondylitis in adults. J Bone Joint Surg Am. 1985; 67:1405-13.

31. Lopez-Sanchez MC, CalvoArrojo G, Vazquez-Rodriguez TR. Tuberculous spondylodiskitis with lumbar tumor. Reumatol Clin 2012; 08:292-3.

32. Martini M, Ouahes M. Bone and joint tuberculosis: a review of 652 cases. Orthopedics. 1988; 6:861866[PubMed]

33. Miskew DB, Block RA, Witt PF. Aspiration of infected sacroiliac joints. J Bone Joint Surg Am 1979; 61(7):10711072 [PubMed]

34. Moujtahid M, Essadki B, Lamine A, Fikry T, Bennouna D, Dkhissi M, Zryouil B. Tuberculous osteitis in limbs. 
Twenty five case-reports. Rev Rheum Engl Ed. 1996; 63(5):344-348. [PubMed]

35. Nicholson RA. Twenty years of bone and joint tuberculosis in Bradford. A comparison of the disease in the indigenous and Asian populations. J Bone Joint Surg Br 1974; 56(4):760-765 [PubMed]

36. Osman AA, Govender S. Septic sacroiliitis. Clin Ortho 1995; 313:214-219 [PubMed]

37. Pertuiset E. Peripheral bone and joint tuberculosis. EMCRheumatologie Orthopedie. 2004; 1:463-86.

38. Punia VPS, Kumar S. Atypical manifestation of sacral tuberculosis as cauda-conus syndrome. JIACM. 2008; 9:57-60.

39. Patankar T, Krishnan A, Patkar D, Kale H, Prasad S, Shah $\mathrm{J}$ et al. Imaging in isolated sacral tuberculosis: review of 15 cases. Skeletal Radiol. 2000; 29:392-6.

40. Pertuiset E, Beaudreuil J, Liote F, Horusitzky A, Kemiche F, Richette $\mathrm{P}$ et al. Spinal tuberculosis in adults:A study of 103 cases in a developed country, 1980-1994. Medicine. 1999; 78:309-20.

41. Pouchot J, Vinceneux P, Barge J, Boussougant Y, Grossin M, Pierre $\mathrm{J}$ et al. Tuberculosis of the sacroiliac joint: clinical features, outcome, and evaluation of closed needle biopsy in 11 consecutive cases. Am J Med. 1988; 84(3 Pt 2):622-628. doi: 10.1016/0002-9343(88)90146 5. [PubMed][Cross Ref]

42. Resnick D, Niwayama G. Osteomyelitis, septic arthritis, and soft tissue infection: organisms. In: Resnick D, editor. Diagnosis of bone and joint disorders. Philadelphia: Saunders; 1995, 2461-2485.

43. Richter R, Nubling W, Kobler G, Iljinski A. Tuberculosis of the iliosacral joints. Treatment, results, prognosis and differential diagnosis. Z Orthop Ihre Grenzgeb. 1983; 121(5):564-570. [PubMed]

44. Shantanu K, Sharma V, Kumar S, Jain S. Tuberculosis of sacrum mimicking as malignancy. BMJ Case Rep, 2012

45. Seddon HJ, Strange FG. Sacroiliac tuberculosis. Br J Surg 28:193-221 Soholt ST (1951) Tuberculosis of the sacroiliac joint. J Bone Joint Surg Am 1940; 33(1):119 129 [PubMed]

46. Salomon CG, Ali A, Fordham EW. Bone scintigraphy in tuberculous sacroiliitis. Clin Nucl Med. 1986; 11(6):407408. [PubMed]

47. Shembekar A, Babhulkar S. Chemotherapy for osteoarticular tuberculosis. Clin Orthop. 2002; 398:2026.[PubMed]

48. Vaiopoulos G, Sfikakis PP, Velikas E, Kittas C, Kaklamanis P. Tuberculosis of the sacroiliac joint. Eur Spine J. 1997; 6(5):330-331. [PubMed]

49. Wellons JC, Woods CW, Eastwood JD, Woods CW, Lawson WT, Eastwood JD. Sacral tuberculosis: a case report and review of the literature. Surg Neurol 2004; 61:136-41.

50. Watts HG, Lifeso RM. Tuberculosis of bones and joints. J Bone Joint Surg [Am] 1996; 78(2):288-298. [Pub Med

51. Yao DC, Sartoris DJ. Musculoskeletal tuberculosis. Radiol Clin North Am. 1995; 33(4):679689. 